\title{
Determination of Heavy Metals in Hoplobatrachus occipitalis (Crowned Bullfrogs) and Water from Some Reservoirs in Kadawa Irrigation Project Kano, Nigeria
}

\author{
${ }^{1 * K U I W A, ~ T S ; ~}{ }^{2} \mathrm{MBAH}, \mathrm{CE} ;{ }^{3}$ ABOLUDE, DS; ${ }^{3} \mathrm{LAWAL}, \mathrm{N} ;{ }^{3}$ AMINU, MA \\ ${ }^{*}$ S School of Basic and Remedial Studies, Funtua, Katsina, ${ }^{2}$ Department of Zoology, ${ }^{3}$ Department of Biology, Faculty of Life Science, \\ Ahmadu Bello University, Zaria, Nigeria \\ *Corresponding Author Email: tasiusalehkuiwa@gmail.com; Tel: 07068355044
}

\begin{abstract}
This study was carried out to evaluate the concentrations of heavy metals $(\mathrm{Cd}, \mathrm{Cu}, \mathrm{Mn}, \mathrm{Pb}$, and $\mathrm{Zn})$ in water and crowned bullfrog (Hoplobatrachus occipitalis) organs/parts (muscle, liver, leg, lung and trunk) from Kadawa irrigation project, Kano State, Nigeria. Atomic Absorption Spectroscopy was carried out using Atomic Absorption Spectrometer (AAS) Buck Scientific VGP-210 model (2008). The mean concentration of heavy metals in water samples were $0.11 \mathrm{mg} / \mathrm{L}, 0.18 \mathrm{mg} / \mathrm{L}, 0.26 \mathrm{mg} / \mathrm{L}$, and $3.65 \mathrm{mg} / \mathrm{L}$ for $\mathrm{Cu}, \mathrm{Mn}, \mathrm{Pb}$ and $\mathrm{Zn}$ respectively. The sequence of metal accumulation in all the organs was $\mathrm{Zn}>\mathrm{Pb}>\mathrm{Mn}>\mathrm{Cu}$. The highest concentration of $\mathrm{Zn}(77.38 \mathrm{mg} / \mathrm{kg}), \mathrm{Pb}(1.81 \mathrm{mg} / \mathrm{kg})$ and $\mathrm{Mn}(0.68 \mathrm{mg} / \mathrm{kg})$ were found in the lung while $\mathrm{Cu}(0.07 \mathrm{mg} / \mathrm{kg})$ was deposited more in the liver. Cadmium was not detected in all the samples analysed. Zinc and lead were the most accumulated metals in all the organs/parts with the range of $77.38 \mathrm{mg} / \mathrm{kg}-18.10 \mathrm{mg} / \mathrm{kg}$ and $1.81 \mathrm{mg} / \mathrm{kg}-0.13 \mathrm{mg} / \mathrm{kg}$ respectively. The highest accumulation of metals was found in the lung and liver. The organ/parts accumulation pattern was: lung $>$ liver $>$ trunk $>$ muscle $>$ leg for $\mathrm{Zn}, \mathrm{Pb}$ and $\mathrm{Mn}$, while liver $>$ lung $>$ trunk $>$ muscle $>$ leg was for $\mathrm{Cu}$. Lung and liver have the highest bioaccumulation of heavy metals while the leg and muscle bioaccumulated the least heavy metals. Hence the water, liver and lung of $H$. occipitallis are unsafe for consumption, and therefore posed a threat to public health. Farmers should be trained on proper usage of agrochemical.
\end{abstract}

DOI: https://dx.doi.org/10.4314/jasem.v23i12.8

Copyright: Copyright $\left({ }^{C} 2019\right.$ Kuiwa et al. This is an open access article distributed under the Creative Commons Attribution License (CCL), which permits unrestricted use, distribution, and reproduction in any medium, provided the original work is properly cited.

Dates: Received: 30 November 2019; Revised: 17 December 2019; Accepted: 23 December 2019

Keywords: Heavy Metals, Crowned Bullfrog, Hoplobatrachus occipitalis, Kadawa, Bioaccumulation

Most environmental problems are as a result of production of goods and services which leads to the release of pollutants that eventually accumulates in water. Because all other life forms depend directly or indirectly on water, aquatic pollution is often regarded as one of greater concern (Faye-ofori et al., 2015). Most of our water resources are gradually becoming polluted due to the addition of foreign materials from the surroundings. Lower aquatic organisms absorb and transfer them through the food chain to higher trophic levels, including fish (Ijeoma et al., 2015). Kadawa Irrigation Project is one of the modern irrigation farming area in Nigeria, especially Kano state. Farmers in the area engaged in different farming activities to increase productivity. Efforts toward increasing agricultural productivity and food security are focused on fertilizer and other agrochemicals as a remedy for declining soil quality and stagnant yields. Agrochemicals (pesticides and fertilizers) are considered as a vehicle for improved crop production technology though it is a costly input. Balance use, optimum doses, correct method and right time of application of agrochemicals ensures increased crop production (Bhandari, 2014). There is currently world- wide concern regarding the impact of these modern farming practices on soil and water quality (Ogbodo and Onwa, 2013). Agricultural runoff often contains developed levels of heavy metals from agrochemicals applied to the fields. These chemicals are carried with rainfall runoff into rivers, streams and reservoirs, polluting water bodies and modifying aquatic habitats (Ogbodo and Onwa, 2013). The water reservoirs of Kadawa irrigation area are used for farming activities and as a source of crowned bullfrogs (Hoplobatrachus occipitalis) which are transported to other part of Nigeria and consumed as source of protein. This study focused on the assessment of heavy metals in the water and crowned bullfrogs in Kadawa Irrigation Area. Different organs and parts of the frogs were analysed and compared for heavy metals concentration. Frogs are amphibians in the order Anura (from Greek word an - without and oura - tail), formerly referred to as Salientia (from Latin word salere -"to jump"). The Order Anura contains 4,810 species in 33 families, of which the Leptodactylidae (1100 spp.), Hylidae ( 800 spp.) and Ranidae (750 spp.) are the richest in species. About $88 \%$ of amphibian species are frogs (Oduntan et al., 2012). Frogs are ancient animals that have been 
around for about 200 million years (David and Carola, 2009). Frogs highly permeable skin means they can rapidly absorb toxic substances. The use of frogs and toads, as biological indicators of metal pollution is becoming more common (Burger and Snodgrass, 1998).

The Crowned bullfrog (Hoplobatrahus occipitals) (Günther, 1858), is an important species of Anurans that is considered a delicacy as local people catch them for food due to their taste and fleshy legs. $H$. occipitalis is a species of frog in the Dicroglossidae family. It is found in the Sub-Saharan Africa (Abosede et al., 2016). It naturally inhabits both aquatic and terrestrial areas therefore making it an excellent sentinel animal (Mitchell, 2000; IUCN SSC Amphibian Specialist Group, 2014). They are also highly prolific, easy to handle and comparatively economical to use for field evaluation and as an experimental model (Abosede et al., 2016). Frogs have been eaten in Europe for centuaries, but after the Second World War demand escalated. An increase in the size of human population tends to increase the existing pressure on wildlife resources population (Akinyemi and Efenakpo, 2015). Frog legs are consumed in many part of the world. The leading importer for frog legs worldwide is EU, with France $23 \%$, Belgium $53 \%$, Italy $6 \%$ and Netherland $17 \%$ being the major destination (Sandra et al., 2011). Tao et al. (2012) found that $\mathrm{Zn}$ and $\mathrm{Cu}$ are the most likely to be accumulated in all aquatic organisms of different tropic levels. Taiwo et al. (2014) analysed $H$. occipitalis and reported that there was widespread heavy metal pollution in Lagos State emanating from diverse sources and bioaccumulative potentials of measured heavy metals in $H$. occipitalis in Lagos metropolis raises salient pollution management questions. Nasir et al., (2017) determined Zn concentrations in different tissues (liver and kidney) of $R$. tigrina from different habitats (canal water, fish pond and sewage water) and reported that liver tissues of $R$. tigrina taken from all the three habitats contain higher levels of $\mathrm{Zn}$ than kidney samples. Therefore, the objective of this paper is to evaluate the concentrations of selected heavy metals such as $\mathrm{Cd}$, $\mathrm{Cu}, \mathrm{Mn}, \mathrm{Pb}$ and $\mathrm{Zn}$ in Water samples and organs/body parts (muscle, liver, leg and trunk) of Crowned bullfrog (Hoplobatrahus occipitals) from Kadawa irrigation project, Kano State, Nigeria.

\section{MATERIALS AND METHODS}

Study Area: Kadawa irrigation project is part of the Kano River Project lies on both sides of Kano-Zaria and Kano-Rano roads, positioned in Garun Malam Local Government area in southern part of Kano State. Kadawa is enclosed between latitude $\left(11^{\circ} 35^{\prime} \mathrm{N}\right.$ and $\left.11^{\circ} 50^{\prime}\right)$ and longitude $\left(08^{\circ} 25^{\prime} \mathrm{E}\right.$ and $08^{\circ} 35^{\prime} \mathrm{E}$ ) (Adamu, et al., 2014). The area has been identified as an area where mechanized and intensive irrigation activities are taking place. The climate of Kano State (Kadawa inclusive) is the tropical wet and dry type. The temperature is averagely warm to hot throughout the year at about $25^{\circ} \mathrm{C} \pm 7^{\circ} \mathrm{C}$ (Olofin and Tanko, 2002).

Sampling and Sample Preparation: Samples (frogs, catfishes and water) were collected weekly for three months (October, November, and December 2018). A total of 36 frogs (14 males and 22 females) were collected from the three locations: A (Dorawar sallau), B (Kadawa) and C (Gafan) reservoirs. The samples collected were prepared for heavy metal analysis.

Samples collection: The frog samples were caught using rod and line fishing tools, bait (piece of meat) was tightened onto the line to attract the frogs without using hook, when the frog swallow the bait it is then pulled out of the water without any injury. The frog samples caught were taken to the Zoological Museum Department of Zoology, Ahmadu Bello University, Zaria for identification. The sexes of the frogs were recorded. Guide lines for human use of animals for scientific research as contained in ABU Committee on Animal Use and Care (ABUCAUC) was strictly followed.

Samples preparation: Frog samples were washed and dissected respectively; while livers, lungs, muscle, trunks and legs were collected and prepared for analysis. The organs and tissues collected were ovendried for three days at $105^{\circ} \mathrm{C}$. Dried samples were pulverized to powder in a porcelain mortar using a pestle after which they were weighed using Mettler MP600 model electric balance, stored in Ziploc bags and labeled prior to acid digestion.

Samples Digestion: Digestion was done in accordance with Millam, et al. (2015) with little modification. Powdered organ digestion was carried out by adding $1 \mathrm{~g}$ of each pulverized organ into $1000 \mathrm{~cm}^{3}$ flasks, $10 \mathrm{~cm}^{3}$ of distilled de-ionised water was added to the samples, followed by $10 \mathrm{~cm}^{3}$ of concentrated $\mathrm{HNO}_{3}$. The mixture was boiled at $100^{\circ} \mathrm{C}$ for 60 minutes then allowed to cool, after which $5 \mathrm{~cm}^{3}$ of $\mathrm{H}_{2} \mathrm{SO}_{4}$ was added to the cooled mixture and heated again at $140^{\circ} \mathrm{C}$ for 20 minutes until a dense white fume of $\mathrm{H}_{2} \mathrm{SO}_{4}$ was observed. The solution was allowed to cool and transferred into $100 \mathrm{~cm}^{3}$ volumetric flask and diluted using distilled de-ionised water to a final volume of $100 \mathrm{~cm}^{3}$ and then stored in a plastic bottle for Atomic Absorption Spectrometry (A.A.S.) analysis.

Water sample collection and preparation: Water samples were randomly collected in sampling bottles; 
pre-conditioned with 5\% nitric acid and later rinsed thoroughly with distilled de-ionised water. At each sampling site, the plastic sampling bottles were rinsed at least three times water at the sampling stations before collecting the samples. The sampling bottles were immersed about $10 \mathrm{~cm}$ below the water surface. About $0.5 \mathrm{~L}$ of water sample was collected at each sampling site. Samples were acidified with $10 \%$ $\mathrm{HNO}_{3}$, placed in an ice bath and brought to the laboratory. The samples were filtered through a 0.4 $\mu \mathrm{m}$ micropore membrane Whatman filter and kept at $4^{\circ} \mathrm{C}$ until analysis (Ozturk et al., 2009).

Heavy Metals analysis: Digested samples were analysed for Cadmium (Cd), Copper ( $\mathrm{Cu})$, Lead (Pb), Manganese (Mn) and Zinc (Zn) using Atomic Absorption Spectrometer (AAS) Buck Scientific VGP-210 model (2008). Air acetylene was used as lean fuel, appropriate hollow cathode lamp for each element determined was employed. Blank and standard solutions were aspirated and the absorbance readings in nanometers were recorded. Three separate absorbance readings were taken for each sample aspirated and their average values computed. The concentration of heavy metals was calculated using the formula (Olaifa et al., 2004).

***Kindly crosscheck this equation and make the necessary corrections

Actual concentration of metal in Sample $=$ PPMR X Dilution factor

Where; PPMR $=$ AAS reading of Digest.
Dilution factor $=\frac{(\text { volume of digest used })}{\text { weight of sample digested }}$

The Bioaccumulation factor (BF) of heavy metals was calculated using the formula (Djibrine et al., 2018)

$\mathrm{BF}=\frac{\text { Concentration of Heavy Metal in Animal Tissue }}{\text { Concentration of Heavy Metal in Animal Tissue }}$

Statistical Analyses: Mean concentration of heavy metals in the samples was obtained at 5\% level of significance using Analysis of variance (ANOVA). Duncan's Multiple Range Test (DMRT) was used in separating the means where significant difference was observed. All analyses were performed using SPSS V21.0.

\section{RESULTS AND DISCUSSION}

The analysis of heavy metals concentration was carried out to assess the levels of some heavy metals in organs/parts of Hoplobatrachus occipitalis and water in Kadawa Irrigation Project, Kano. A total of thirty six (36) H. occipitalis and water sample each were collected from three different locations in Kadawa Irrigation Project within the period of August to December 2018. The samples collected were analysed for $\mathrm{Cd}, \mathrm{Cu}, \mathrm{Mn}, \mathrm{Pb}$ and $\mathrm{Zn}$. In all the samples analysed $\mathrm{Cd}$ was found to be below the detection limit by Atomic Absorption Spectrometer (AAS) Buck Scientific VGP-210 model (2008). The physicochemical parameters in water analysed were: Temperature $\left(27.0-25.4{ }^{0} \mathrm{C}\right), \mathrm{pH}(8.0-7.5)$, Dissolved Oxygen (3.5-3.1 mg/l), Total Dissolved Solids (50.1$40.2 \mathrm{mg} / \mathrm{l})$ and Electric Conductivity (111.8-84.4 $\mu \mathrm{S} / \mathrm{cm})$.

Table 1: Heavy Metals in Organs/Parts of Hoplobatrachus occipitalis (Crowned bullfrog) and Different Permissible Limits

\begin{tabular}{llllll}
\hline Organs & $\mathbf{C d}(\mathbf{m g} / \mathbf{k g})$ & $\mathbf{C u}(\mathbf{m g} / \mathbf{k g})$ & $\mathbf{M n}(\mathbf{m g} / \mathbf{k g})$ & $\mathbf{P b}(\mathbf{m g} / \mathbf{k g})$ & $\mathbf{Z n}(\mathbf{m g} / \mathbf{k g})$ \\
\hline Muscle & ND & $0.07 \pm 0.01^{\mathrm{c}}$ & $0.06 \pm 0.04^{\mathrm{b}}$ & $0.20 \pm 0.04^{\mathrm{b}}$ & $18.10 \pm 2.28 \mathrm{~b}^{\mathrm{c}}$ \\
Liver & ND & $1.21 \pm 0.20^{\mathrm{a}}$ & $0.61 \pm 0.07^{\mathrm{a}}$ & $1.78 \pm 0.22^{\mathrm{a}}$ & $42.99 \pm 5.18^{\mathrm{b}}$ \\
Leg & ND & $0.09 \pm 0.02^{\mathrm{c}}$ & $0.06 \pm 0.02^{\mathrm{b}}$ & $0.17 \pm 0.03^{\mathrm{b}}$ & $16.43 \pm 1.18^{\mathrm{c}}$ \\
Lung & ND & $0.48 \pm 0.08^{\mathrm{b}}$ & $0.68 \pm 0.10^{\mathrm{a}}$ & $1.81 \pm 0.30^{\mathrm{a}}$ & $77.38 \pm 14.14^{\mathrm{a}}$ \\
Trunk & ND & $0.10 \pm 0.03^{\mathrm{c}}$ & $0.12 \pm 0.02^{\mathrm{b}}$ & $0.13 \pm 0.02^{\mathrm{b}}$ & $23.06 \pm 1.50 \mathrm{~b}^{\mathrm{c}}$ \\
p-value & - & 0.000 & 0.000 & 0.000 & 0.000 \\
FAO (1983)\# & 0.05 & 30 & 1.0 & 0.5 & 30 \\
FAO/WHO(1989)\# & 0.5 & 30 & 0.5 & 0.5 & 40 \\
FEPA(2003)\# & - & $0.5-1.5$ & 0.05 & - & $5-10$ \\
USFDA(2001)\# & - & 1.3 & 0.05 & - & 5
\end{tabular}

Note: Values with different superscript differ significantly at $p \leq 0.05$. Average number of frogs $=36 . ;$ Key: $N D=$ Not detected by Atomic Absorption Spectrometer (AAS) Buck Scientific VGP-210 model, \# = Maximum permissible limit in fish and fishery products.

Table 1 shows significant difference in heavy metals concentration between different organs/parts. Zinc was reported to be accumulated more in all the organs of $H$. occipitalis. High accumulation of $\mathrm{Zn}$ in all the organs/parts of frogs may be due to the specific adaptive mechanism of the frogs to absorb $\mathrm{Zn}$ from the habitat for onward transfer to kidney for metabolism. It may also be from agro-chemicals (fungicides) used in the farms as reported by Qureshi et al., (2015). This is in line with the finding of Taiwo et al., (2014) who recorded high concentration of $\mathrm{Zn}$ in tissue of $H$. occipitalis. Zinc concentration differs significantly between the organs studied ( $p$-value $=0.00$ ). The concentration of $\mathrm{Zn}$ in all the parts/organs of frog was found to be above the $5-10 \mathrm{mg} / \mathrm{kg}$ permissible limit of FEPA (2003) and also above the FAO/WHO (1989) and FAO (1983) permissible limits of $40 \mathrm{mg} / \mathrm{kg}$ and $30 \mathrm{mg} / \mathrm{kg}$ in lungs and livers respectively. There was 
significant difference observed in the concentration of $\mathrm{Pb}$ among different organs/parts of frogs ( $\mathrm{p}$-value $=$ $0.00)$. Concentration of $\mathrm{Pb}$ in the lungs and livers was above the FAO/WHO (1989) permissible limit of 0.5 $\mathrm{mg} / \mathrm{kg}$ but below the limit in muscle, trunk and leg. This is in line with the report of Amuzie and Daka (2018) who recorded higher concentration of $\mathrm{Pb}$ in liver of $H$. occipitallis in Niger Delta. This may be connected to the use of inorganic fertilizer as stated by Raymond and Felix (2011) that compounds used to produce fertilizers contain trace amounts of heavy metals such as $\mathrm{Cd}$ and $\mathrm{Pb}$ as impurities. All these can get into water as runoff or get into the frog through feeding on herbivorous insects. Manganese concentration in the organs/parts was above the 0.05 $\mathrm{mg} / \mathrm{kg}$ permissible limit of FEPA (2003) but below FAO (1983) permissible limit of $1.00 \mathrm{mg} / \mathrm{kg}$. Concentration of $\mathrm{Mn}$ in organs/parts of frog differed significantly ( $\mathrm{p}$-value $=0.00)$. Manganese distribution pattern in organs was: lung $>$ liver $>$ trunk $>$ leg, with the lung having the highest $(0.68 \mathrm{mg} / \mathrm{kg})$ and least in the muscle and leg (0.06) each. Copper was recorded more in liver with mean value of $1.21 \mathrm{mg} / \mathrm{kg}$ and less in muscle with a value of $0.07 \mathrm{mg} / \mathrm{kg}$. Qureshi et al., (2015) also reported high level of $\mathrm{Cu}$ in Rana tigrina in Pakistan. Organ/parts accumulation pattern of $\mathrm{Cu}$ was: liver $>$ lung $>$ trunk $>$ leg $>$ muscle which is also in concordance with the findings of Amuzie and Daka (2018) who reported the similar pattern of $\mathrm{Cu}$ accumulation (liver $>$ lung $>$ gut $>$ muscle). Although there was high accumulation of $\mathrm{Cu}$ in the liver and lung the level was below the FAO/WHO (1989) permissible limit of $30.0 \mathrm{mg} / \mathrm{kg}$ and $0.5-1.5 \mathrm{mg} / \mathrm{kg}$ of FEPA (2003). All the heavy metals studied accumulated more in the lung and liver.

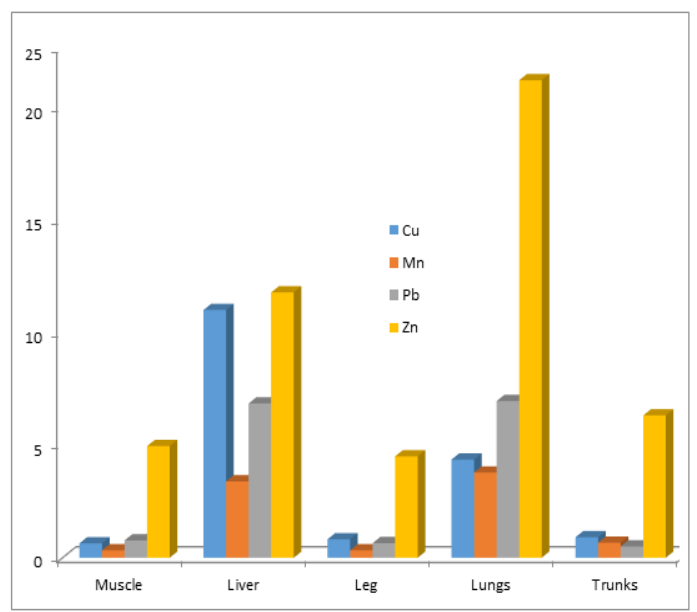

Fig 1: Bioaccumulation of heavy metals in Hoplobatrachus occipitalis (Crowned bullfrog) organs/parts.

This agreed with the finding of Bawuro (2018) who recorded more heavy metals in the lung of fish and
Qureshi et al., (2015) who recorded more metals in the liver of frogs. Lung accumulated more heavy metals likely because of its prominent function in gaseous exchange (Singh et al., 2011). High heavy metals concentration in the liver may be attributed to the fact that liver act as an organ mostly associated with detoxification of toxic chemicals that entered the body (Soufy et al., 2007). Shaapera et al., (2013) also reported high concentration of $\mathrm{Cu}$ and $\mathrm{Cd}$ in the liver. Bioaccumulation of heavy metals in organs/parts of $H$. occipitalis as shown in figure 1 indicate that Lung was found to have highest bioaccumulation of $\mathrm{Zn}, \mathrm{Pb}$ and Mn with mean values of $21.1 \mathrm{ppm}, 6.96 \mathrm{mg} / \mathrm{kg}$ and $3.78 \mathrm{mg} / \mathrm{kg}$ respectively. This could be due to the respiratory function of the lung which lead to accumulation of the heavy metals from the air (Singh et al., 2011). Tyokumbur and Okorie (2011) also reported higher bioaccumulation of $\mathrm{Zn}(29.84 \mathrm{mg} / \mathrm{kg})$ in Rana esculentus. Lawal-Are et al., (2017) in their work reported higher $\mathrm{Zn}$ concentration in Lagoon crab and Shrimp. Liver has more bioaccumulation of $\mathrm{Cu}$ with mean value of $11.00 \mathrm{mg} / \mathrm{kg}$. Higher bioaccumulation of $\mathrm{Cu}$ in the liver may be due to its high chemical metabolism (Bawuro, 2018). Bioaccumulation pattern in organs was in the order of lung $>$ liver $>$ trunk $>$ muscle $>$ leg for $\mathrm{Zn}, \mathrm{Pb}$ and $\mathrm{Mn}$, while liver $>$ lung $>$ trunk $>$ leg $>$ muscle pattern was for $\mathrm{Cu}$. In general lung and liver have higher bioaccumulation of heavy metals.

Heavy metal accumulation in frogs may adversely affect the function of different systems and behavior patterns of the amphibians (Brunt et al., 2012; Singha et al. 2014) Result in Table 2 shows that higher concentration of all the heavy metals were recorded in water in Location A, followed by location B, and the least were found in Location $\mathrm{C}$. The pattern of heavy metals accumulation in water across locations was: A $>\mathrm{B}>\mathrm{C}$. This may be attributed to the fact that Water in location A was closer to the express way just $50 \mathrm{~m}$ away while location B was $200 \mathrm{~m}$ from express way and location $\mathrm{C}$ was $1000 \mathrm{~m}$ from express way. This shows that location A may be more polluted due to vehicular exhaust. Chiroma et al., (2014) also reported more heavy metal in irrigation water from Kano city that has more traffic congestion than irrigation water from Yola with less traffic congestion. Taiwo et al., (2019) also stated that heavy metals variation in water may be due to level of pollution, oxygen concentration and transparency. Although all the metals analysed were more in location $\mathrm{A}$ compared to $\mathrm{B}$ and $\mathrm{C}$ but statistically only $\mathrm{Zn}$ and $\mathrm{Pb}$ concentrations were significantly different between the locations (P-value $=0.012$ and 0.000 ) respectively. . 
Table 2: Heavy Metal Concentration in Water in different Locations and Different Permissible Limits

\begin{tabular}{llllll}
\hline & \multicolumn{5}{c}{ Heavy metals } \\
\hline Locations & Cd (mg/L) & $\mathbf{C u ~ ( m g / L ) ~}$ & $\mathbf{M n}(\mathbf{m g} / \mathbf{L})$ & $\mathbf{P b}(\mathbf{m g} / \mathbf{L})$ & $\mathbf{Z n}(\mathbf{m g} / \mathbf{L})$ \\
\hline Loc. A & ND & $0.13 \pm 0.05^{\mathrm{a}}$ & $0.22 \pm 0.02^{\mathrm{a}}$ & $0.33 \pm 0.02^{\mathrm{a}}$ & $4.35 \pm 0.20^{\mathrm{a}}$ \\
Loc. B & ND & $0.11 \pm 0.01^{\mathrm{a}}$ & $0.19 \pm 0.03^{\mathrm{ab}}$ & $0.26 \pm 0.02^{\mathrm{b}}$ & $3.78 \pm 0.46^{\mathrm{ab}}$ \\
Loc. C & ND & $0.09 \pm 0.01^{\mathrm{a}}$ & $0.15 \pm 0.02^{\mathrm{b}}$ & $0.17 \pm 0.00^{\mathrm{c}}$ & $2.80 \pm 0.33^{\mathrm{b}}$ \\
p-value & - & 0.699 & 0.058 & $0.000^{*}$ & $0.012^{*}$ \\
FEPA (1991)\# & - & 1.0 & 0.1 & - & 0.5 \\
WHO (2006)\# & 0.003 & 0.5 & 0.1 & 0.01 & 0.3 \\
SON (2002)\# & 0.003 & 1.0 & 0.05 & 0.01 & 3.0 \\
\hline
\end{tabular}

Note: Values with different superscript differ significantly at $\mathrm{p} \leq 0.05$. Keys: $\mathrm{ND}=$ Not detected by Atomic Absorption Spectrometer (AAS) Buck Scientific VGP-210 model. * $=\mathrm{P}<0.05$, \#= Maximum permissible limit in water, Loc. $A=50 \mathrm{~m}$ from Expressway, Loc. $\mathrm{B}=200 \mathrm{~m}$ from Expressway, Loc. C =1,000m from Expressway

There was no significant difference in the concentrations of $\mathrm{Mn}$ and $\mathrm{Cu}$ in all the locations $(\mathrm{P}$ value $=0.058$ and 0.699 respectively). $\mathrm{Zn}$ concentrations in all the locations were found to be above the FEPA (1991) and WHO (2006) permissible limits of $0.5 \mathrm{ppm}$ and $0.3 \mathrm{ppm}$ and below the SON (2002) permissible limit of 3.0ppm in locations A and B. This was similar to the finding of Uzairu et al., (2014) who observed highest value of $\mathrm{Zn}$ in water during hot season. Lead $(\mathrm{Pb})$ concentration in all the locations ranged from $0.33 \mathrm{mg} / \mathrm{L}$ to $0.17 \mathrm{mg} / \mathrm{L}$, which was above the permissible limits of $0.01 \mathrm{mg} / \mathrm{L}$ recommended by SON (2002) and WHO (2006). High lead concentration in the water may be from the fertilizer, pesticides and vehicular exhaust (Raymond and Felix, 2011). Concentration of $\mathrm{Cu}$ in all the locations was below the permissible limits of $1.0 \mathrm{mg} / \mathrm{L}$ of SON (2002) and FEPA (1991) and $0.5 \mathrm{mg} / \mathrm{L}$ set by $\mathrm{WHO}(2006)$. This is in line with the findings of Uzairu et al., (2014) who reported that $\mathrm{Cu}$ was generally within the recommended limits.

Conclusion: There was $\mathrm{Zn}, \mathrm{Pb}$ and $\mathrm{Mn}$ pollution in both the frog and water from diverse sources in the area under study. $\mathrm{Zn}$ and $\mathrm{Pb}$ was the most accumulated heavy metals in the frog organs/parts and water and were above the various standard permissible limis. Lung and liver have the highest bioaccumulation of heavy metals while the leg and muscle have the least. Hence the water, liver and lung of $H$. occipitallis are unsafe for consumption, and therefore posed a threat to public health. Consumers should go for the leg and muscle, internal organs should be avoided.

Acknowledgements: The authors wish to acknowledge the contributions of Mal. Magaji of Hydrobiology Laboratory, Department of Biology Ahmadu Bello University Zaria and A.M. Hashim of Soil Laboratory, Geography Department Bayero University Kano for digestion and analysis of the samples.

\section{REFERENCES}

Abosede, OO; Afusat, JJ; Oluwatobi, FA; Augustine, A A (2016). Cadmium Bio- Accumulation and the Associated Biomarkers in Edible Frog Species (Hoplobatrachus occipitalis) in Ibadan, Oyo State, Nigeria. World Vet. J. 6(2): 7079.

Adamu, GK; Aliyu, AK; Jabbi, AM (2014). Fertility Assessment of Soils under Rice Cultivation in Kadawa, Garun Mallam Local Government, Kano State. Natural and Appl. Sci. 5(1): 92-99.

Akinyemi, AF; Efenakpo, OD (2015). Frog Consumption Pattern in Ibadan, Nigeria. J. for Stds. in Manage. and Planning 1(3): 522-231.

Amuzie, CC; Daka, ER (2018). Heavy Metal Concentrations in Soil and Tissues of Haplobatrachus occipitalis From an Oilfield and Suburban Location in the Niger Delta. J. of Nigerian Environ. Society (JNES), 12(1): 84-95.

Bawuro, AA; Voegborlo, R B; Adimado, AA (2018). Bioaccumulation of Heavy Metals in Some Tissues of Fish in Lake Geriyo, Adamawa State, Nigeria. Hindawi Jnal of Environ. and Pub. Health, doi.org/10.1155/2018/1854892.

Bhandari, G (2014). An Overview of Agrochemicals and Their Effects on Environment in Nepal. Appl. Ecol. and Enviro. Sci. 2(2): 6673.DOI:10.12691/aees-2-2-5.

Burger, J; Snodgrass, J (1998). Heavy Metals in Bullfrog (Rana catesbeiana) Tadpoles: Effects of Depuration before Analysis. Environ. Toxicology and Chem. 17: 2203-2209.

Chiroma, TM; Ebewele, RO; Hymore, FK (2014). Comparative Assessement of Heavy Metal Levels in Soil, Vegetables and Urban Grey Waste Water Used for Irrigation in Yola and Kano. Internl. Refereed J. of Eng. and Sci. 3(2): 01-09. 
David, B; Carola, H (2009). Frog Biodiversity and Conservation. Sustaining America's Aquatic Biodiversity. publication 420-527.

Djibrine, AO; Guira, F; Abdelsalam, T; Nodjimadji, R; Madjimbaye, P; Tarnagda, B; Savadogo, A (2018). Risks Assessments of Heavy Metals Bioaccumulation in Water and Tilapia nilotica from Maguite Island, Fitri Lake. Currt. J. of Appl. Sci. and Techn. 26(2): 19.

FAO/WHO (1989), “WHO technical report series No 505, Evaluation of certain food additives and the contaminants, mercury, lead and cadmium for environment monitory report No 52 center for environment," Tech. Rep., Fisheries And Aquaculture Science Lowest Toft UK.

Faye-ofori, GB; Okorinama, A (2015). Heavy Metal Concentration in Some Organs of Clarias gariepinus (African Catfish) From Okilo Creek, Rivers State, Nigeria. Annals. of Biol. Research, 611: 68-71.

FEPA (Federal Environmental Protection Agency), 2003. Guidelines and Standards for Environmental Pollution and Control in Nigeria. pp.238.

Ijeoma, KH; Onyoche, EN; Uju, OV; Chukwuene, IF ( 2015). Determination of Heavy Metals in Fish (Clarias gariepinus) Organs from Asaba Major Markets, Delta State, Nigeria. Americ. Chem. Sci. J. 5(2): 135-147.

Lawal-Are, AO; Mokwenye, CR; Akinwunmi, MF (2017). Heavy Metal Bioaccumulation in Callinectes amnicola And Farfantepenaeus notialis From Three Selected Tropical Water Bodies in Lagos, Nigeria. Ife J. of Sci. 19(2): 247254. doi.org/10.4314/ijs.v19i2.5

Mitchell, JC (2000). Diversity and distribution of Amphibians and Reptiles. In: Sparling, D. W., Linder, G. and Bishop, C. A., (eds) 2000. Ecotoxicology of amphibians and reptiles. Pensacola, FL: Society of Environmental Toxicology and Chemistry (SETAC). pp. 15-71.

Millam, C; Dimas, BJ; Jang, AL; Eneche, JE (2015). Determination of Some Heavy Metals in Vital Organs of Cow and Bulls at Jimeta Abattoir Yola, Adamawa State, Nigeria. Amer Chem. Sci. J. 8(4): $1-7$..
Nasir, M; Ansari, TM; Yasin, G; Shoaib, M; Mudassir, MA; Khan, AA (2017). Bioaccumulation of zinc in Rana tigrina in different aquatic habitats. Afr. J. of Biotech. 16(17): 921-927. DOI: 10.5897/AJB2016.15443.

Oduntan, OO; Akintunde, OA; Oyatogun, MOO; Shotuyo, ALA; Akinyemi, AF (2012). Proximate Composition and Social Acceptability of SunDried Edible Frog (Rana esculenta) in Odeda Local Government Area, Nigeria. PAT journal 8. (1): 134-143.

Ogbodo, EN; Onwa, NC (2013). Impact of Long-term Application of Agrochemicals on the AgroEcology of the Lower Anambra River Basin Southeast Nigeria. J. of Enviro. and Earth Sci. 3(5): 32-37.

Olaifa, FE; Olaifa, AK; Adelaja, AA; Owolabi, AG (2004). Heavy Metal Contamination Of Clarias gariepinus From A Lake And Fish Farm In Ibadan, Nigeria. Afri. J. of Biomed. Research, 7: 145 - 148. http://www.bioline.org.br/md

Olofin, EA; Tanko, AI (2002). Laboratory of Areal Differentiation: Metropolitan Kano in Geographical Perspective. Geography Department: Bayero University, Kano.

Öztürk, MG; Özözen, O; Minareciand, EM (2009). Determination of Heavy Metals in Fish, Water and Sediments of Avsar Dam Lake in turkey.Iran. J. of Environ. Health Sci. and Eng. 6(2): 73-80.

Qureshi, I.Z., Khashir, Z., Hashim, M.Z., Su, X., Malik, R.N., Ullah, K.,Hu, K. and Dawood, M. (2015). Assessment of heavy metals and metaloiods in tissue of two frogs species, Rana tigrina and Euphlyctis cyanophylyctis for industrial city Sialkot, Pakistan. Environ. Sci. and poll. research, 22(18): 14157-14168.

Raymond, AW; Felix, EO (2011). Review Article Heavy Metals in Contaminated Soils: A Review of Sources, Chemistry, Risks and Best Available Strategies for Remediation.

Sandra, A; Alejandra, G; Schubert, D.J. (2011). Canapés to Extinction, The International Trade In Frog's Legs And Its Ecological Impact (Report).

Shaapera, U; Nnamonu, LA; Eneji, LS (2013). Assessment of heavy metals in Rana esculenta organs from River Guma, Benue State, Nigeria. Amer. J. of Analy. Chem. 4(9): 496-500. 
Singh, R; Neetu, G; Anurag, M; Rajiv, G (2011). Heavy metals and living systems: An overview. Indian j. of Pharmaco. 43(3): 246-253.

Singha, U; Neelam, P; Freeman, B (2014). Sodium arsenite induced changes in survival, growth, metamorphosis and genotoxicity in the Indian cricket frog (Rana limnocharis). Chemosphere, 112: 333-339.

SON (2002). Nigerian Standard for Drinking Water Quality, Revised edition 2007.

Soufy, H; Soliman, M; Elmanakhly, E; Gaafa, A (2007). Some Biocghemical and Pathological Investigations on Monosex Tilapia following chronic exposure to carbofuran pesticides. Global Veterinaria, 1(1): 45-52.

Taiwo, IE; Henry, AN; Imbufe, AP; Adetoro, OO (2014). Heavy metal bioaccumulation and biomarkers of oxidative stress in the wild African tiger frog, Hoplobatrachus occipitalis Afr J. of Environ. Sci. and Tech. 8(1): 6-15 DOI:10.5897/AJEST2013.
Taiwo, IO; Olopade, OA; Bamidele, NA (2019). Heavy Metal Concentration in Eight Fish Species from Epe Lagoon. "The Wetlands Diversity" 21(1): $69-82$.

Tao, Y; Yuan, Z; Xiaona, H; Wei, M (2012). Distribution and bioaccumulation of heavy metals in aquatic organisms of different tropic levels and potential health risk assessment from Taihulake, China. Ecotoxicology Environ. Safety. 81:55-64.

Tyokumbur, ET; Okorie, TG (2011). Macro and Trace Element Accumulation in Edible Crabs and Frogs in Alaro Stream Ecosystem, Ibadan. J. of Research and Nat. Devt. 9(2):439-446.

Uzairu,A; Okunola, OJ; Wakawa, RJ; Adewusi, SG (2014). Bioavailability Studies of Metals in Surface Water of River Challawa, Nigeria. $J$. of Appl. Chem. 1:9. http://dx.doi.org/10.1155/2014/648453.

WHO (2006). World Health Organization Guidelines for Drinking Water Quality (iii) Health Criteria and Supporting Information. World Health Organization, Geneva, $1-515$. 